\title{
Spatial Analyses for the City of Zagreb - Planning and Management
}

\author{
Nives ŠKREBLIN
}

City Office for Strategic Planning and City Development, Republike Austrije 18, 10000 Zagreb, Croatia

nives.skreblin@zagreb.hr

\begin{abstract}
Spatial analyses for the City of Zagreb are mostly produced by the Department for Spatial Information and Research of the Zagreb City Office for Strategic Planning and Development, which is also the coordinator of Zagreb Infrastructure Spatial Data (Croatian acronym: ZIPP). Based on an extensive database, spatial research, analyses, indicators and analytical bases can be accessed for the needs of strategic planners and other users.

Examples from practice are described which are publicly available on the web pages of the City of Zagreb, and which were produced at the request of city administrative bodies or private use, from analyses of population density, access to public transport, access to public green spaces, the network of preschool and primary school facilities, strategic city projects, capital investments in buildings for social activities, and public architecture-urbanism tenders, to registering damage after the earthquakes in Zagreb.

Spatial analyses provide data which encourage the rational use of spatial resources and informed city administration. New features are interactive web applications with publicly available data which achieve transparency on the part of the city administration. One of the advantages is that they can be refreshed in real time.
\end{abstract}

Keywords: spatial analysis, urban analysis, spatial and urban planning, spatial data, GIS, Zagreb

\section{Introduction}

Spatial analyses are an essential basis and integral part of preparatory work for high quality spatial and urban planning. The goal is to acquire data for a given area through analysis, leading to balanced development, the rational development of spatial resources and improving the quality of life. The results of such analysis are better if the work is interdisciplinary and includes a number of experts, so in the work of the Department for Spatial Information and Research of the Zagreb City Office for Strategic Planning and Development, architects, geodesists, geographers, transport engineers and engineering technicians are all included, while cooperation with structural engineers and other professions is implemented as required.

Spatial and urban analyses for the City of Zagreb are produced by the Sector for Strategic Information and Research of the City Office for Strategic Planning and Development (Croatian acronym: GUSPRG), which dates back to 1929 when the City established the $17^{\text {th }}$ Department for City Regulation, with the task of producing competitive bases for international competitions for the construction, extension and regulation of the City of Zagreb, which continue to this day, among other things (Kahle 2006, Čengić 1995).

GUSPRG is organised in four sectors (Figure 1) which conduct the following activities:

- Producing the Development Strategy for the Urban Agglomeration of Zagreb, of which it is the bearer

- Proposing, preparing and producing strategic decisions and plans regarding the development of the City

- Participating in the preparation and production of the City's development projects

- Proposing partner projects with other regions and participants, project presentations, cooperation with scientific institutions in relation to the concept of the City's development

- Producing and adopting spatial plans

- Establishing the City's strategic interest in terms of strategic and other development projects

KiG No. 33, Vol. 19, 2020 https://doi. org/10.32909/kg.19.33.3 - 


\title{
Prostorne analize Grada Zagreba - planiranje i upravljanje
}

\author{
Nives ŠKREBLIN \\ Gradski ured za strategijsko planiranje i razvoj Grada, Republike Austrije 18, 10000 Zagreb \\ nives.skreblin@zagreb.hr
}

\begin{abstract}
Sažetak. Prostorne analize za Grad Zagreb velikim dijelom izrađuje Odjel za prostorne informacije i istraživanja Gradskog ureda za strategijsko planiranje i razvoj Grada, koji je ujedno koordinator Zagrebačke infrastrukture prostornih podataka. Temeljem bogate baze podataka izrađuju se prostorna istraživanja, analize, pokazatelji i analitičke podloge za potrebe strategijskog planiranja te druge potrebe i korisnike.

Opisani su primjeri iz prakse koji su javno dostupni na web stranicama Grada Zagreba, a izrađeni su na zahtjeve gradskih upravnih tijela ili za vlastite potrebe - od analize gustoće stanovništva, dostupnosti javnog prijevoza, dostupnosti javnih zelenih površina, mreže dječjih vrtića i osnovnih škola, strateških gradskih projekata, kapitalnih ulaganja u objekte za društvene djelatnosti, javnih arhitektonsko-urbanističkih natječaja do prijave šteta nakon potresa u Zagrebu.

Prostorne analize daju podatke kojima se potiče racionalno korištenje prostornih resursa i pametno upravljanje gradom. Novost su interaktivne web aplikacije s javno dostupnim podatcima kojima se postiže transparentnost gradske uprave, a njihova je prednost osvježavanje podataka u stvarnom vremenu.
\end{abstract}

Ključne riječi: prostorna analiza, urbanistička analiza, prostorno i urbanističko planiranje, prostorni podatci, GIS, Zagreb

\section{Uvod}

Prostorne su analize obavezna podloga i sastavni dio pripremnih radova za kvalitetno prostorno i urbanističko planiranje. Cilj je analizama dobiti podatke za zadani prostor kojima se potiče uravnoteženi razvoj, racionalno korištenje prostornih resursa i poboljšanje kvalitete života. Rezultati analiza su kvalitetniji ako je rad interdisciplinaran i u njemu sudjeluje veći broj stručnjaka. Tako u Odjelu za prostorne informacije i istraživanja Gradskog ureda za strategijsko planiranje i razvoj Grada Zagreba rade arhitekti, geodeti, geografi, inženjer prometa i građevinski tehničar, a obavezna je suradnja sa statističarima i drugim stručnjacima po potrebi.

Za Grad Zagreb prostorne i urbanističke analize izrađuje Sektor za strategijske informacije i istraživanja Gradskog ureda za strategijsko planiranje i razvoj Grada (GUSPRG), čija je povijest započela davne 1929. godine kada je Grad osnovao XVII. Odsjek za regulaciju grada sa zadaćom izrade natječajnih podloga za međunarodni natječaj za izgradnju, proširenje i regulaciju grada Zagreba, čime se Ured, između ostaloga, bavi i danas (Kahle 2006, Čengić 1995).

GUSPRG je organiziran $u$ četiri Sektora (slika 1)

koji obavljaju sljedeće poslove:

- nositelji su izrade Strategije razvoja Urbane aglomeracije Zagreb

- predlažu, pripremaju i izrađuju strategijske odluke i planove o razvoju Grada

- sudjeluju u pripremi i provedbi razvojnih projekata Grada

- predlažu partnerske projekte s regijama i drugim subjektima, prezentacije projekata, suradnju sa znanstvenim institucijama $u$ vezi $s$ konceptom razvoja Grada

- izrađuju i donose prostorne planove,

- utvrđuju strategijski interes Grada u vezi sa strateškim i drugim razvojnim projektima

- vode infrastrukturu prostornih podataka i drugih podataka od interesa za strategijsko planiranje i razvoj Grada 
GRAD ZAGREB

Gradski ured za strategijsko planiranje i razvoj Grada

CITY OF ZAGREB

Zagreb City Office for Strategic Planning and Development

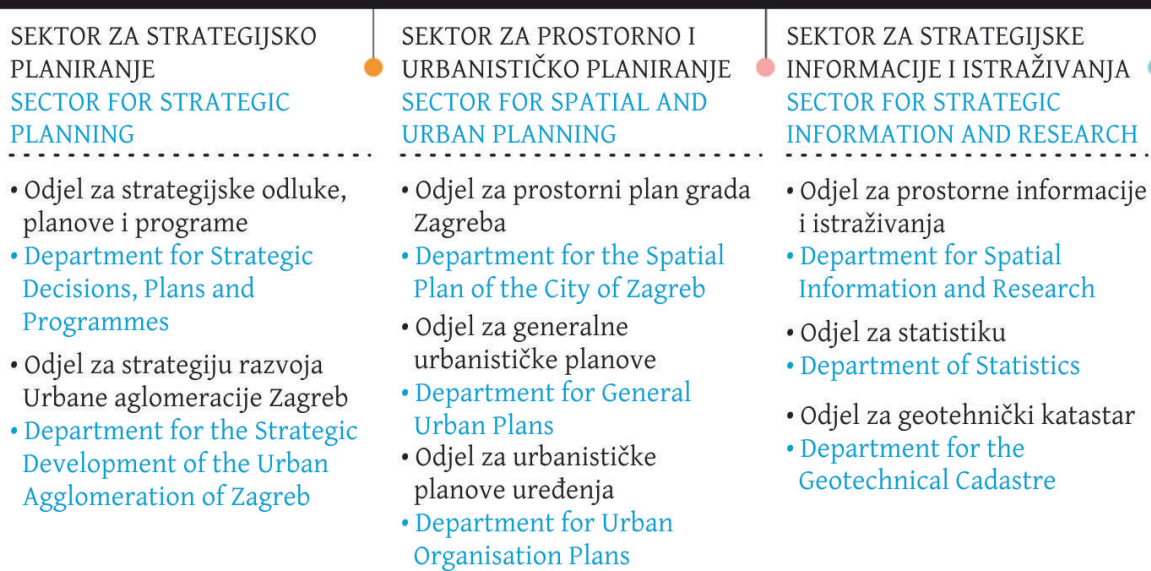

SEKTOR ZA

RAZVOJ GRADA

SECTOR FOR CITY

DEVELOPMENT

- Odjel za strateške gradske projekte

- Department for Strategic City Projects

- Odjel za pripremu i provedbu

regionalnih i međunarodnih projekata

- Department for the Preparation and

Implementation of Regional and

International Projects

- Odjel za prezentaciju projekata

(ZAGREBFORUM)

- Department for Project Presentation

(ZAGREBFORUM)
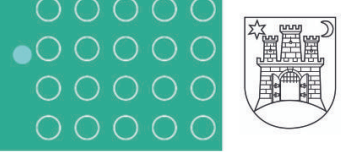

GRAD ZAGREB

GRADSKI URED ZA

STRATEGIJSKO PLANIRANJE

I RAZVOJ GRADA

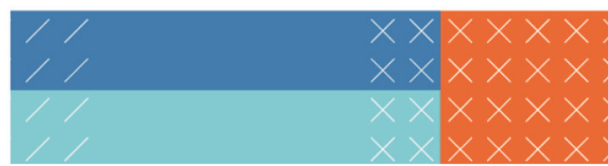

Fig. 1 Organisation of the Zagreb City Office for Strategic Planning and Development. Source: GUSPRG.

Slika 1. Ustrojstvo Gradskog ureda za strategijsko planiranje i razvoj Grada, izvor: GUSPRG.

- lead the infrastructure of spatial and other data of City's interest for strategic planning and development

- Processing data statistically and other tasks within its competence (GUSPRG 2020).

At the national level, the GUSPRG represents the City of Zagreb as a subject in the National Spatial Data Infrastructure (Croatian acronym: NIPP) and reports sources of spatial data on the NIPP geoportal for several city administration bodies (OG 2013, 2018). In addition, the GUSPRG is the coordinator of the NIPP and publishes spatial data on the NIPP geoportal (2020), which is its access point. The geoportal includes data from city administration bodies, commercial companies and institutions, and is the central location for finding, searching and using the spatial data of the City of Zagreb.

The Sector for Strategic Information and Research, of which the Department for Spatial Information and Research is a part, deals with the integration of spatial information and statistics and the adoption of better decisions in the administration of the City.
The Department for Spatial Information and Research provides support for city administration bodies in producing spatial data databases, maintaining, managing and publishing them, and based on these data, conducting tasks related to the implementation of spatial research and analyses and the production of indicators to be used in the City's strategic planning and development, and for other purposes and users, with the preparation of spatial data for producing planning documents as part of regional development policies and the production of analytical bases for proposing priorities in preparing City development drafts and priorities related to strategic city projects and other development projects. It proposes priorities in the production and acquisition of multifunctional spatial bases, systematically monitors processes in the area of the City, cooperates with all subjects which lead sectoral spatial data systems and scientific and expert institutions (Sector 2010), and at the request of citizens and other users, publishes spatial data and conducts an open data policy.

Depending on the area under observation, the City of Zagreb occupies an urban area of $250 \mathrm{~km}^{2}$

KiG No. 33, Vol. 19, 2020, https://doi.org/10.32909/kg.19.33.3 - - 


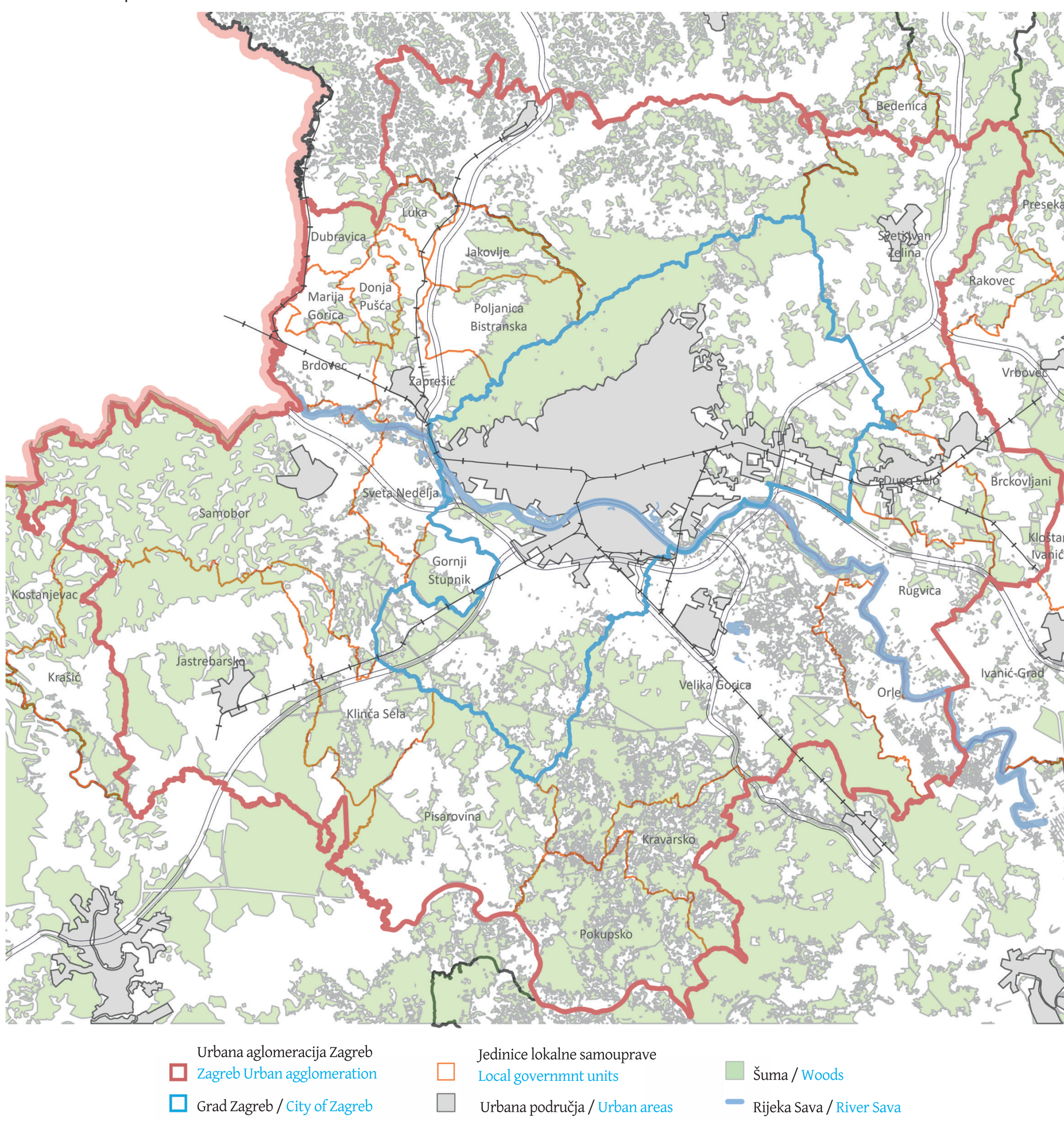

Slika 2. Urbana aglomeracija Zagreb, izvor: GUSPRG.

Fig. 2 Urban agglomeration of Zagreb. Source: GUSPRG.

- statistički obrađuju podatke i obavljaju druge poslove koji su mu stavljeni u nadležnost (GUSPRG 2020).
$\mathrm{Na}$ nacionalnoj razini GUSPRG predstavlja Grad Zagreb kao subjekt Nacionalne infrastrukture prostornih podataka (NIPP) te prijavljuje izvore prostornih 


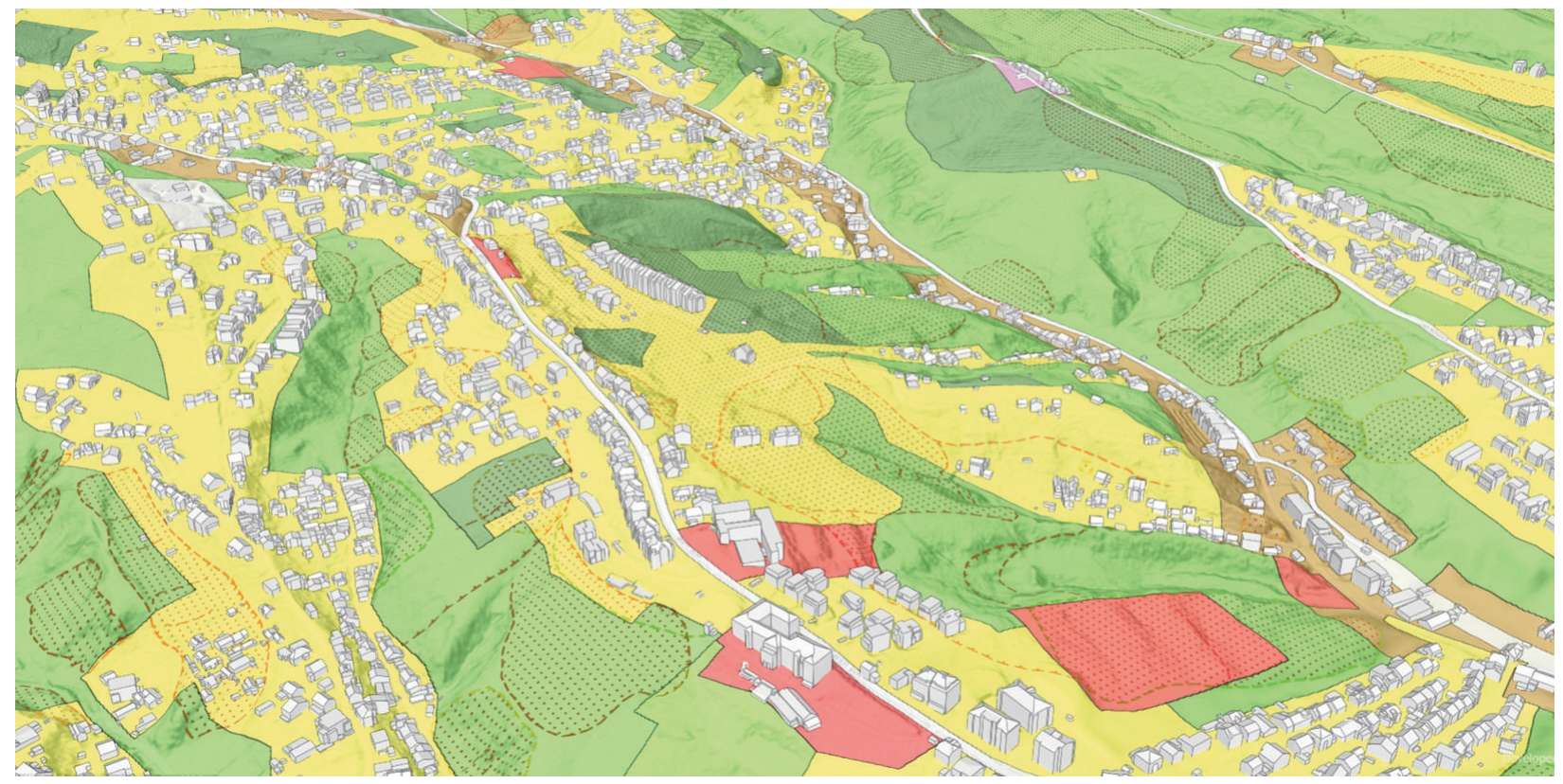

Fig. 3 3D model of the urban part of the City of Zagreb, ZG3D. Source: GUSPRG.

Slika 3. 3D model urbanog dijela grada Zagreba ZG3D, izvor: GUSPRG.

where according to the 2011 population census (DZS 2020) 700,000 residents live, and $640 \mathrm{~km}^{2}$ of an administrative area where 800,000 residents live. The urban agglomeration of Zagreb occupies $2,900 \mathrm{~km}^{2}$ where 1,100,000 residents live (Figure 2).

Spatial analyses are produced for existing city areas, urban units, undeveloped city areas, new regulation zones, and for areas of urban transformation and spatial transformation. Entry date are needed along with existing conditions, norms and criteria for particular topics, along with tools for producing analyses.

Urban analyses deal with existing urban areas and their characteristics, and may be historical, thematic (land use, traffic, public spaces, green infrastructure, construction fund or social content for given spatial ranges), while the results of analyses are indicators for further long-term urban planning. The overall picture can only be seen when all interactions between the various sectoral analyses are taken into consideration, which finally determines the accuracy of an urban analysis. At the beginning of the process, the wider context is observed in order to achieve solutions which can be applied in the narrower area of analysis (Schwalbach 2009).

The City of Zagreb and the GUSPRG have at their disposal a great quantity of spatial data relating to historical spatial plans from the 1970s on, in analogue and (partially) digital formats, a GIS base of the current actual use of space, spatial plans which deal with the future planned development of the City in analogue and digital formats (AF 2019), various bases such as the topographic base, a digital orthophoto, georeferenced statistics, a GIS base of the network of public and social contents, and in addition, a 3D model of the urban part of the City of Zagreb (Figure 3).

The visualisation of spatial data is mostly produced using GIS tools, but the most widely accepted means of depicting spatial data are still analogue cartographic depictions with the most important data and indicators highlighted and adjusted to the scale and spatial range, so that the results of analysis can be shown graphically in a clear and simple way. The basic GIS tools for data processing and the analysis and production of cartographic depictions and presentations are ArcMap, ArcGIS Pro and ArcGIS Online.

\section{Examples of spatial analyses}

Population density in the area of the City of Zagreb urban agglomeration was measured according to Eurostat data (2019) for the needs of the Strategy for the development of the urban agglomeration of Zagreb for the period up to 2020 (Strategy 2020) in two ways: a map of hot spots (Figure 4) and a raster $1 \mathrm{~km} \times 1 \mathrm{~km}$ (Figure 5).

For the Statistical Annals of the City of Zagreb, which is the basic, most comprehensive statistical publication about the city (Annals 2020), maps were prepared of the number of primary and secondary schools in each city district, on which the spatial distribution and number of educational institutions by district was more clearly visible than in the appended tables.

KiG No. 33, Vol. 19, 2020, https://doi.org/10.32909/kg.19.33.3 - - 
podataka na Geoportalu NIPP-a za više gradskih upravnih tijela (Narodne novine 2013, 2018). Osim toga, GUSPRG je koordinator Zagrebačke infrastrukture prostornih podataka (ZIPP) te objavljuje prostorne podatke na Geoportalu ZIPP-a (2020) koji je njegova pristupna točka. Geoportal ZIPP-a sadrži podatke gradskih upravnih tijela, trgovačkih društava i ustanova te je središnje mjesto za pronalaženje, pregled i korištenje prostornih podataka Grada Zagreba.

Sektor za strategijske informacije i istraživanja, unutar kojega je Odjel za prostorne informacije $i$ istraživanja, bavi se integracijom prostornih informacija i statistike za donošenje boljih odluka u upravljanju Gradom.

Odjel za prostorne informacije i istraživanja podrška je gradskim upravnim tijelima za izradu prostornih baza podataka, njihovo održavanje, upravljanje i objavu. Temeljem tih podataka obavlja poslove koji se odnose na provedbu prostornih istraživanja i analiza, izradu pokazatelja za potrebe strategijskog planiranja i razvoja Grada te druge potrebe i korisnike, pripremu prostornih podataka za izradu planskih dokumenata politike regionalnoga razvoja, izradu analitičkih podloga za predlaganje prioriteta u pripremi prijedloga razvoja Grada, kao i prioriteta u vezi sa strateškim gradskim projektima i ostalim razvojnim projektima. Predlaže prioritete za izradu i nabavu višenamjenskih prostornih podloga, sustavno prati procese u prostoru Grada, surađuje sa svim subjektima koji vode sektorske sustave prostornih podataka te znanstvenim i stručnim institucijama (Sektor 2020), a na zahtjeve građana i drugih korisnika izdaje prostorne podatke te provodi politiku otvorenih podataka (open data).

Grad Zagreb, ovisno o promatranom području, zauzima $250 \mathrm{~km}^{2}$ urbanog područja u kojem, prema popisu stanovništva iz 2011. (DZS 2020), živi 700000 stanovnika, $640 \mathrm{~km}^{2}$ administrativnog područja u kojem živi 800000 stanovnika, a Urbana aglomeracija Zagreb zauzima $2900 \mathrm{~km}^{2}$ i u njoj živi 1100000 stanovnika (slika 2).

Prostorne se analize izrađuju za postojeća gradska područja, urbane cjeline, neizgrađena gradska područja, zone nove regulacije, prostore urbanih preobrazbi i prostore transformacije. Za izradu su potrebni ulazni podatci, postojeće stanje, normativi ili kriteriji za određenu temu i alat za izradu analize.

Urbanističke se analize bave postojećim urbanim prostorima i njihovim karakteristikama, mogu biti povijesne analize, analize korištenja zemljišta, prometa, javnih prostora, zelene infrastrukture, građevinskog fonda ili društvenih sadržaja za zadani prostorni obuhvat, a rezultati analiza pokazatelji su za daljnje urbanističko planiranje u dužem vremenskom periodu. Ukupna se slika može vidjeti tek kada se uzmu u obzir interakcije između različitih sektorskih analiza, što u konačnici određuje točnost urbanističke analize. Na početku procesa promatra se širi kontekst kako bi se dobila rješenja primjenjiva $u$ užem analiziranom području (Schwalbach 2009).

Grad Zagreb i GUSPRG raspolažu velikim brojem prostornih podataka koji se odnose na povijesne prostorne planove od 1970-ih nadalje $u$ analognom i djelomično u digitalnom obliku, GIS bazom sadašnjeg postojećeg stvarnog korištenja površina, prostornim planovima koji se bave budućim planiranim razvojem Grada $u$ analognom i digitalnom obliku (AF 2019), raznim podlogama kao što su topografska osnova, digitalni ortofoto, georeferencirana statistika, GIS baza mreže javnih i društvenih sadržaja, a osim navedenoga raspolaže i 3D modelom urbanog dijela grada Zagreba (slika 3).

Vizualizacija prostornih podataka izrađuje se uglavnom GIS alatima, ali je još uvijek najšire prihvaćeni način prikazivanja prostornih podataka analogni kartografski prikaz s istaknutim najvažnijim podatcima i pokazateljima, prilagođen mjerilu i prostornom obuhvatu, pri čemu se rezultate analize grafički jasno i jednostavno prikazuje. Osnovni su GIS alati za obradu podataka, analize, izradu kartografskih prikaza i prezentaciju ArcMap, ArcGIS Pro i ArcGIS Online.

\section{Primjeri prostornih analiza}

Gustoća stanovništva na području Urbane aglomeracije Zagreb pripremljena je prema podatcima Eurostata (2019) za potrebe Strategije razvoja urbane aglomeracije Zagreb za razdoblje do 2020. godine (Strategija 2020) na dva načina: kao karta žarišta (slika 4) i kao raster $1 \mathrm{~km} \times 1 \mathrm{~km}$ (slika 5).

Za potrebe Statističkog ljetopisa Grada Zagreba, koji je temeljna i najopširnija statistička publikacija o Gradu Zagrebu (Ljetopis 2020), pripremljene su karte s brojem osnovnih i srednjih škola po gradskim četvrtima u kojima se jasnije čita prostorni razmještaj i broj obrazovnih ustanova po gradskim četvrtima nego u priloženim tablicama.

Prilikom prijave Grada Zagreba na europske projekte kao što su proGIreg, European Green Capital 2022, Urbact i drugi potrebno je dostaviti podatke o postojećem korištenju površina i planiranim namjenama. Za te je potrebe npr. analiziran javni gradski prijevoz pri čemu je prikazano da $84 \%$ stanovnika 


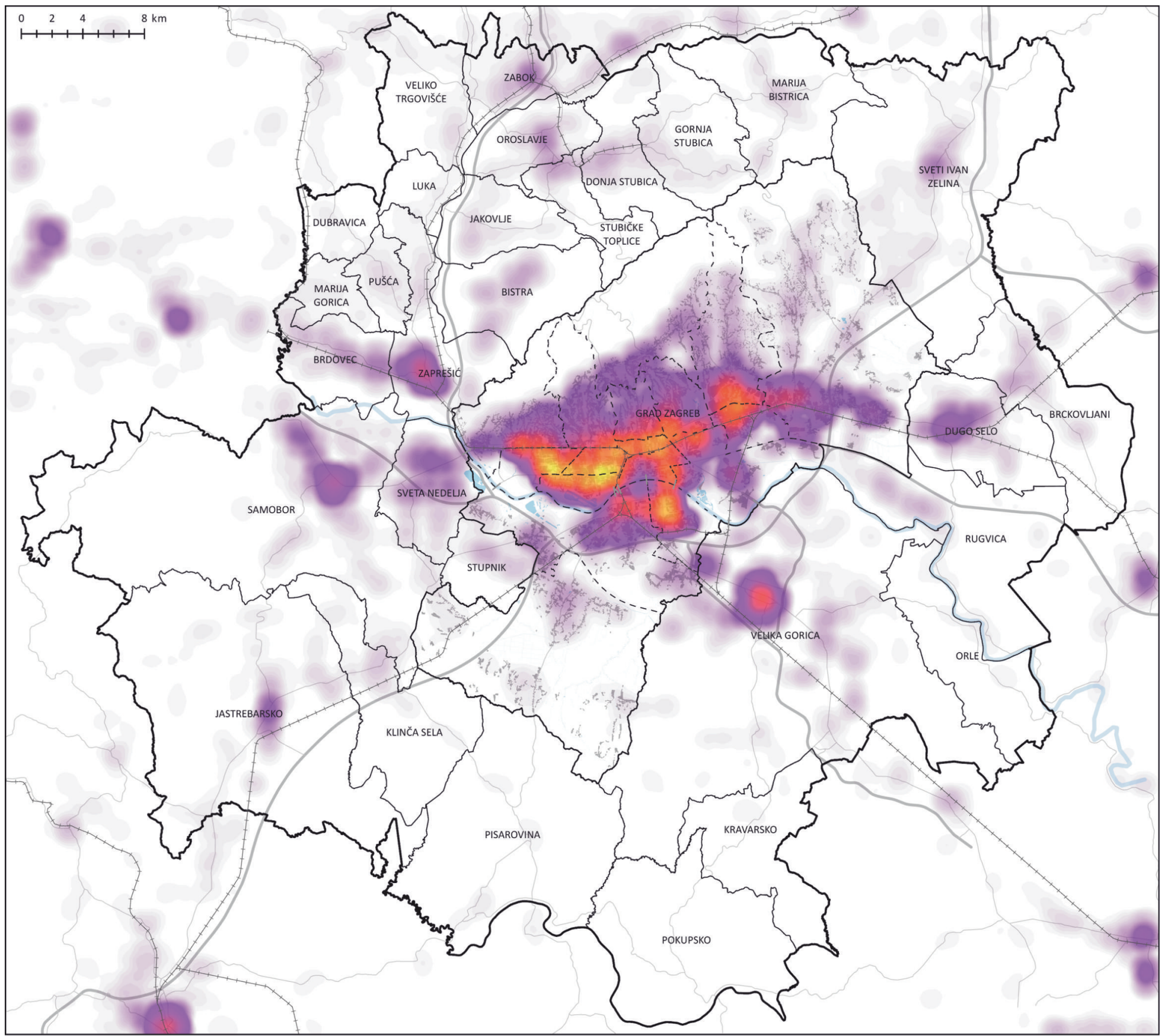

Fig. 4 Population density in the area of the City of Zagreb urban agglomeration - heat map. Source: GUSPRG.

Slika 4. Gustoća stanovništva na području Urbane aglomeracije Zagreb - heatmap, izvor: GUSPRG.

When the City of Zagreb was applying for European projects such as proGIreg, European Green Capital 2022, Urbact and others, it was necessary to provide information on the current and planned use of spaces. An analysis of public transport in the city was carried out, for example, showing that $84 \%$ of the population had access to a tram stop, bus stop or railway station within a radius of 300 metres of their home (Fig. 6), and an analysis of public green spaces showed that $93 \%$ of the population had access to a public green space within a radius of 300 metres of their home (Figure 7).

Networks of preschools and primary schools were prepared in cooperation with the City Office for Education, and the aim was to depict an assessment of the situation regarding preschools and primary schools by city district, and to show the needs in terms of building new facilities. The entry data for these analyses came from the 2011 population census, the existing situation regarding capacities in preschools and primary schools, KiG No. 33, Vol. 19, 2020, https://doi.org/10.32909/kg.19.33.3 - - 


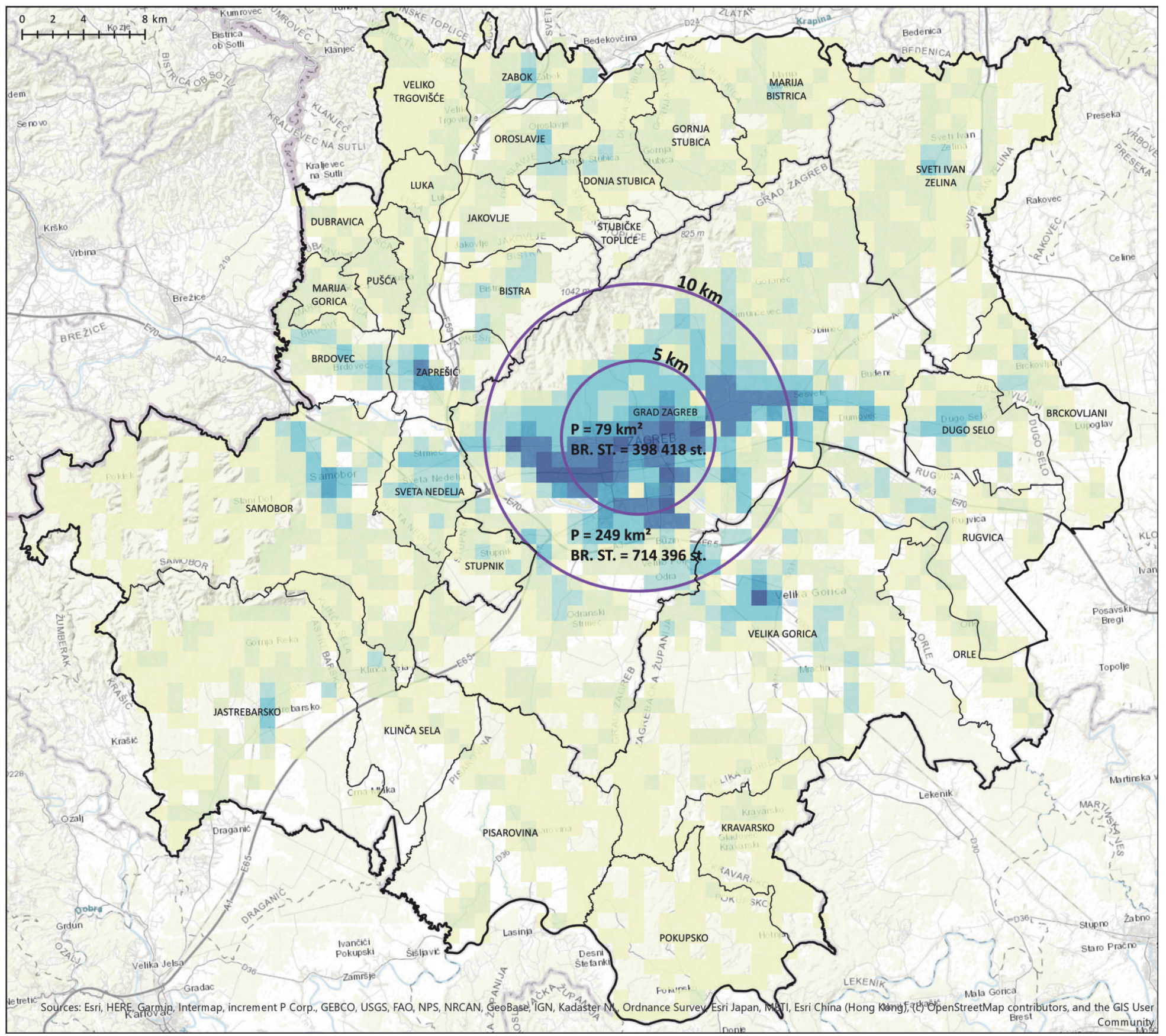

Slika 5. Gustoća stanovništva na području Urbane aglomeracije Zagreb - raster $1 \mathrm{~km} \times 1 \mathrm{~km}$, izvor: GUSPRG.

Fig. 5 Population density in the area of the City of Zagreb urban agglomeration - raster $1 \mathrm{~km} \times 1 \mathrm{~km}$. Source: GUSPRG.

ima dostupnu tramvajsku, autobusnu ili željezničku stanicu $\mathrm{u}$ radijusu od $300 \mathrm{~m}$ (slika 6), odnosno napravljena je analiza javnih zelenih površina koja je pokazala da $93 \%$ stanovnika ima dostupne javne zelene površine u radijusu $300 \mathrm{~m}$ (slika 7).

Mreža dječjih vrtića i Mreža osnovnih škola pripremljena je u suradnji s Gradskim uredom za obrazovanje, a cilj je prikazivanje ocjene stanja dječjih vrtića i osnovnih škola po gradskim četvrtima te iskazivanje potrebe za izgradnjom novih objekata.
Ulazni su podatci za izradu tih analiza Popis stanovništva 2011., postojeće stanje kapaciteta dječjih vrtića i osnovnih škola te planski normativi (Narodne novine 2008a, 2008b, SGGZ 2018) koji ukazuju na planirane potrebe (slika 8).

Na inicijativu Gradskog ureda za zdravstvo i Škole narodnog zdravlja „Andrija Štampar“ koji provode projekt pod nazivom „Ulaganje u rani razvoj djece“ izrađena je „Prostorna analiza patronažne zdravstvene zaštite u domovima zdravlja" koja je poslužila kao jedna 


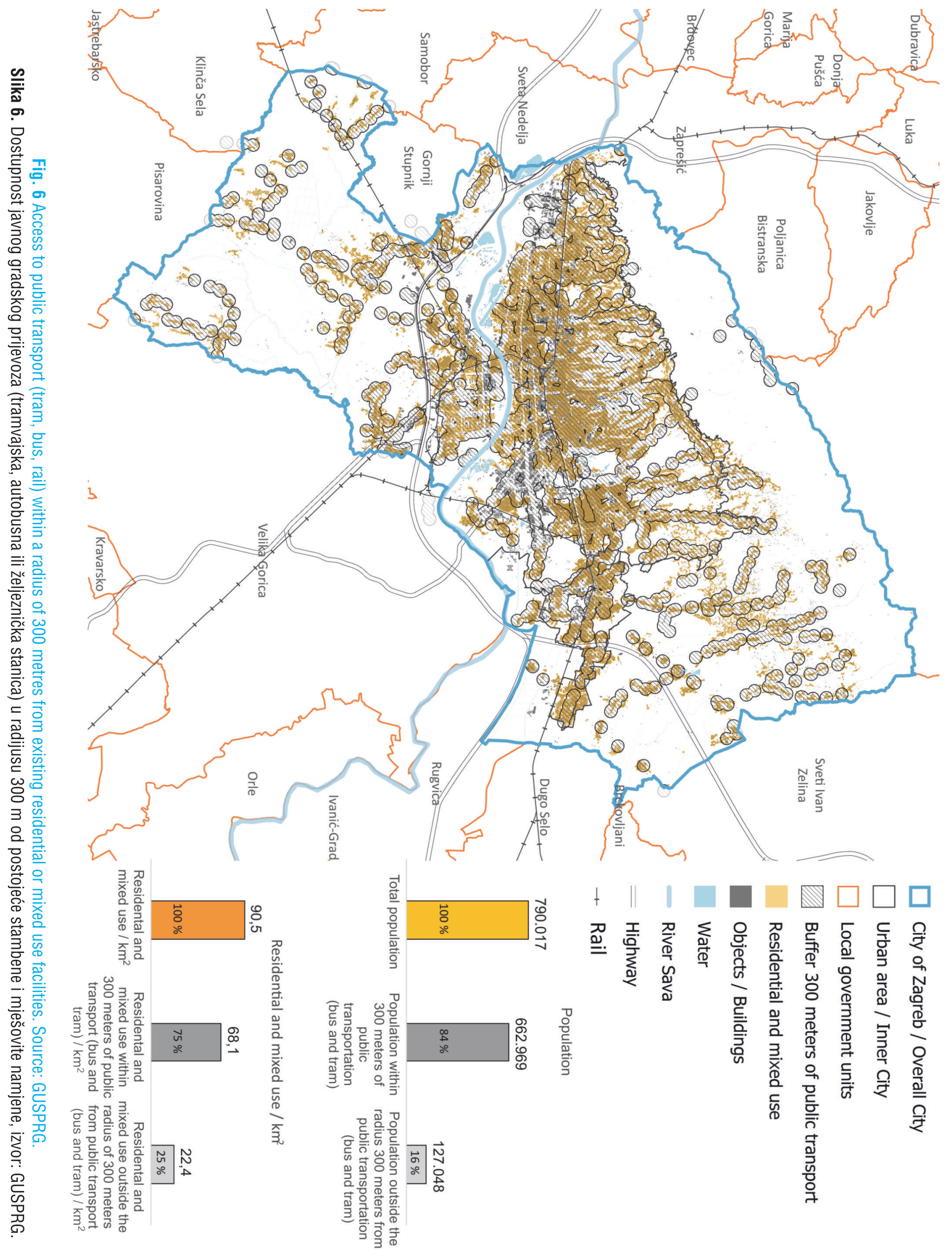



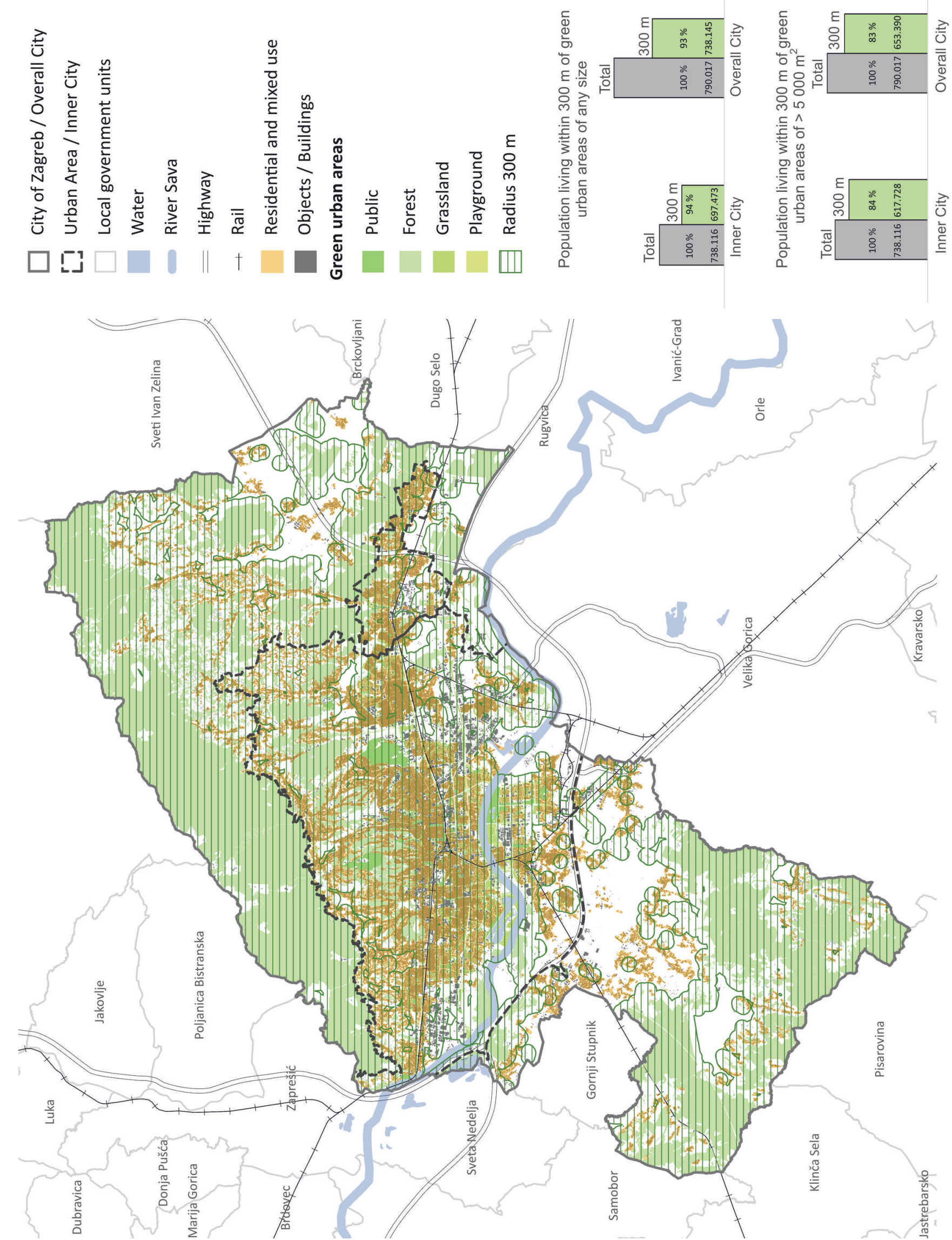

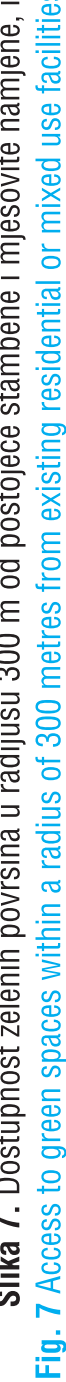




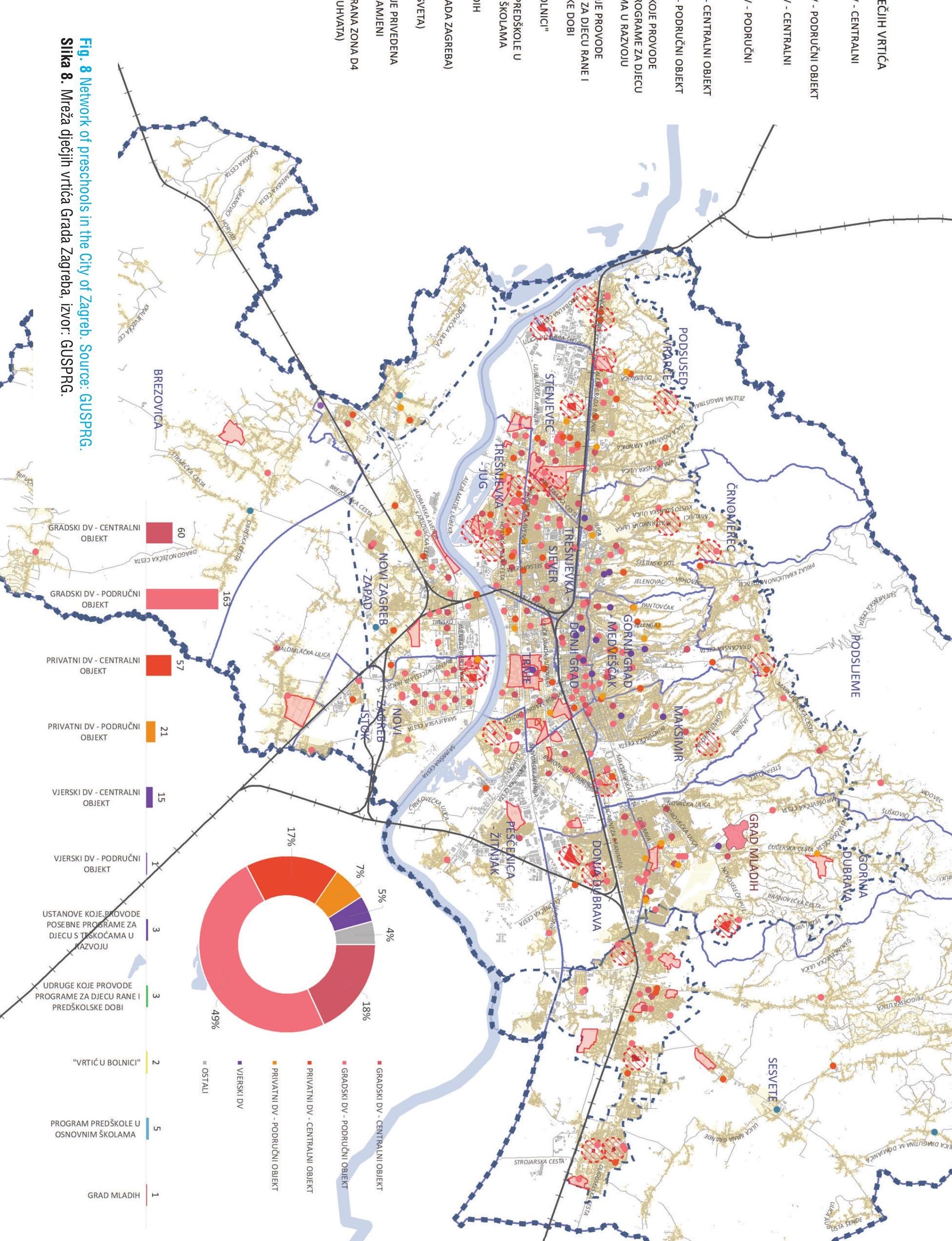



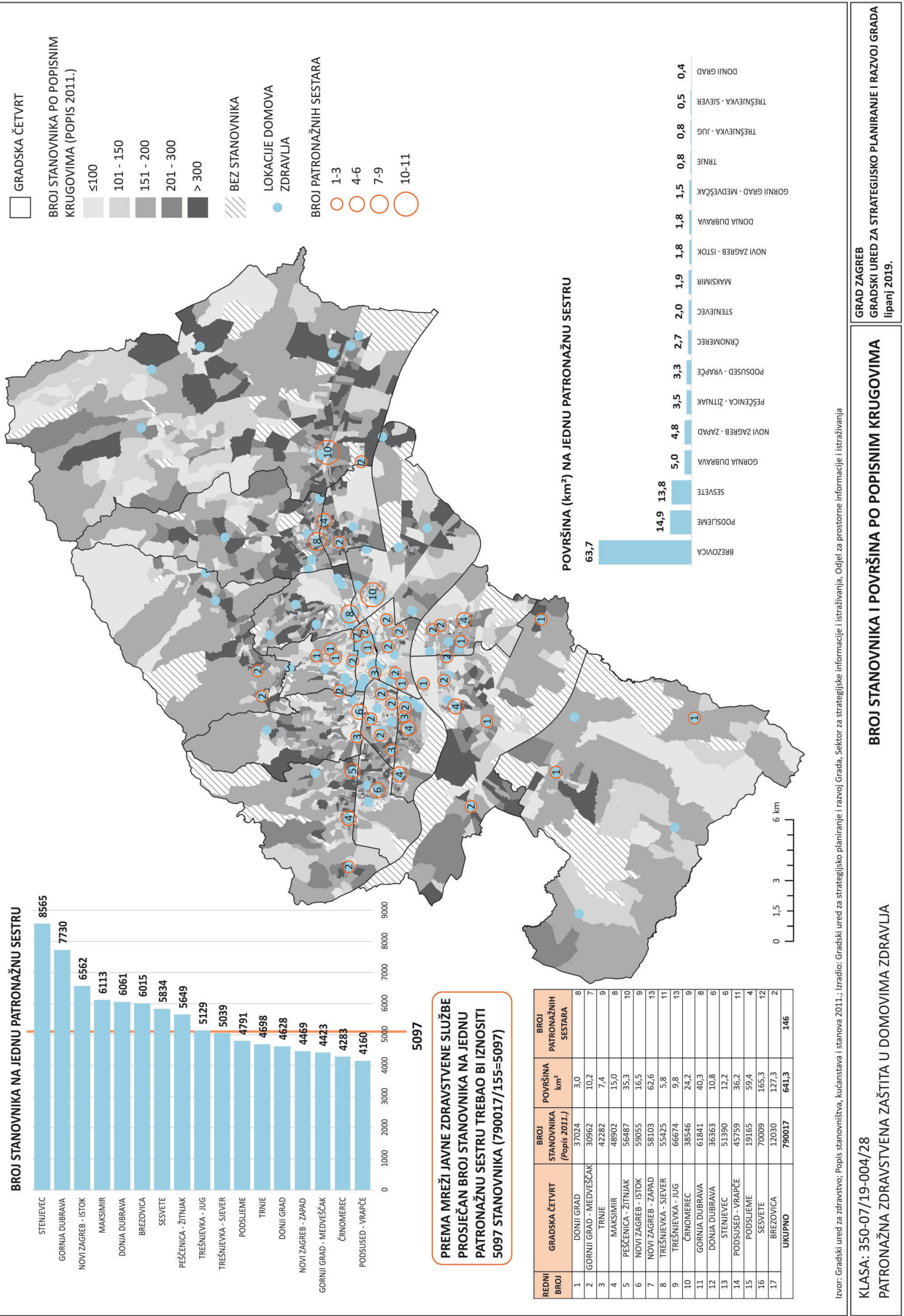

0 


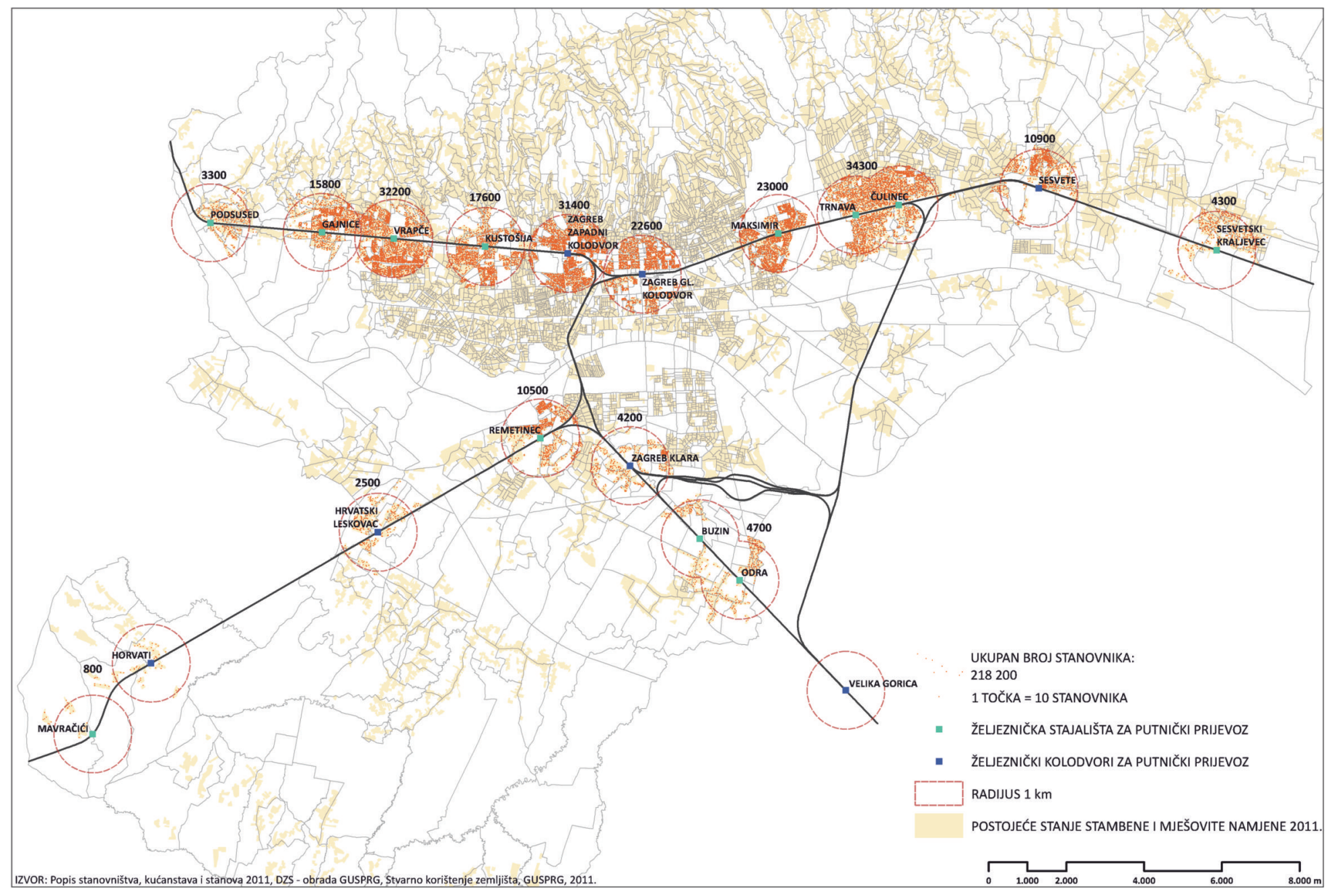

Fig. 10 Analysis of the number of residents who live within a $1 \mathrm{~km}$ radius of existing railways stations. Source: GUSPRG.

Slika 10. Analiza broja stanovnika koji žive u radijusu 1 km od postojećih željezničkih stanica, izvor: GUSPRG.

and planned norms (OG 2008a, 2008b, SGGZ 2018) which indicated planned needs (Figure 8).

At the initiative of the City Office for Health and the Andrija Štampar School of Public Health, which are implementing a project entitled "Investing in Early Child Development", the "Spatial Analysis of Domiciliary Health Care in Health Centres" was produced, which serves as one of the bases for making new decisions and plans in terms of improving the conditions and organisation of domiciliary health care in the City of Zagreb. It is clear that the domiciliary health care teams in some districts are overloaded by population numbers in relation to the prescribed optimum number (Figure 9) according to the network of public health services (OG 2012).

The spatial analysis of the rail network revealed interested details which indicate that according to the 2011 census, 218,000 residents living within a radius of $1 \mathrm{~km}$ gravitated towards the existing rail structure
(Figure 10), 335,000 living with a radius of $1 \mathrm{~km}$ from existing or planned stations, and as many as 398,000 living within a radius of $1 \mathrm{~km}$ from a railway line (Figure 11). The analysis indicated the great spatial potential of railways as part of public transport for almost half the residents of the City of Zagreb, and with the introduction of a 'Park and Ride' system, this could be extended to other residents in the urban agglomeration.

For the strategic city projects of the Sector for City Development of the GUSPRG, spatial analyses were conducted of Gredel and Paromlin, Park Novi Zagreb, the new Hippodrome (Figure 12), the International University Sports Campus, and other sites.

Apart from analogue maps and published detailed plans, the official website of the city publishes interactive spatial analyses displaying spatial data as web applications. The major advantages of these are the fact that they can be updated simply in real time, as re-

KiG No. 33, Vol. 19, 2020, https://doi.org/10.32909/kg.19.33.3 - - 


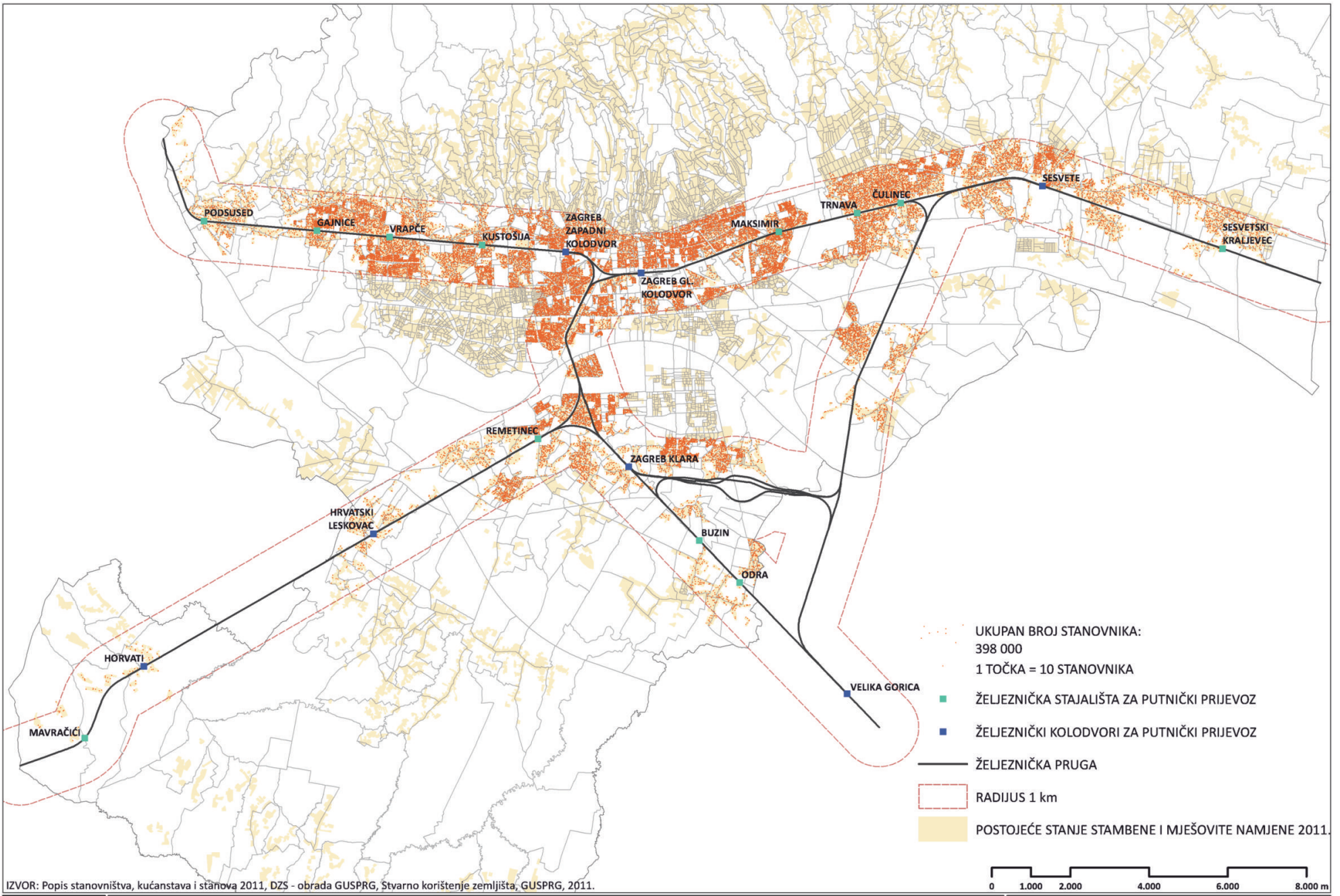

Slika 11. Analiza broja stanovnika u radijusu $1 \mathrm{~km}$ od željeznice, izvor: GUSPRG.

Fig. 11 Analysis of the number of residents who live within a $1 \mathrm{~km}$ radius of railway lines. Source: GUSPRG.

od podloga za donošenje novih odluka i planova vezanih uz poboljšanje uvjeta i organizacije patronažne zdravstvene zaštite na području Grada Zagreba jer je vidljivo u kojoj je gradskoj četvrti tim patronažne zdravstvene zaštite preopterećen brojem stanovnika u odnosu na propisani optimalni broj (slika 9) prema Mreži javne zdravstvene službe (Narodne novine 2012).

Prostorna analiza željeznice pokazuje zanimljive podatke koji ukazuju da prema Popisu 2011. na postojeću željezničku infrastrukturu gravitira 218000 stanovnika koji žive u radijusu do $1 \mathrm{~km}$ od postojećih željezničkih stanica (slika 10), 335000 stanovnika živi u radijusu do $1 \mathrm{~km}$ od postojećih i planiranih željezničkih stanica, a čak 398000 stanovnika u radijusu do $1 \mathrm{~km}$ od željezničke pruge (slika 11). Analiza ukazuje na veliki prostorni potencijal željeznice kao dijela javnog gradskog prijevoza za gotovo pola stanovnika Grada Zagreba, a uz izgradnju parkirališta park\&ride i za stanovnike urbane aglomeracije.
Za strateške gradske projekte Sektora za razvoj grada GUSPRG-a izrađene su prostorne analize Gredelj i Paromlin, Park Novi Zagreb, novi Hipodrom (slika 12), Međunarodni sveučilišni sportski kampus i druge.

Osim analognih karata i objave elaborata, na službenim su stranicama Grada objavljene i interaktivne prostorne analize s prikazom prostornih podataka kao web aplikacije, pri čemu je najveća prednost jednostavno ažuriranje podataka u stvarnom vremenu jer su osvježeni podatci odmah dostupni i smanjena je potreba za izradom novih analognih prikaza.

S obzirom na to da je GUSPRG i nositelj izrade prostornih planova, za Sektor za prostorno i urbanističko planiranje pripremljena je web aplikacija u kojoj je vidljiva statistika urbanističkih planova uređenja u odnosu na Prostorni plan Grada Zagreba i Generalne urbanističke planove Zagreba i Sesveta, a moguće je izdvojiti planove prema pretežitosti namjene, godini donošenja, statusu donošenja i gradskoj četvrti (Planovi 2020). 


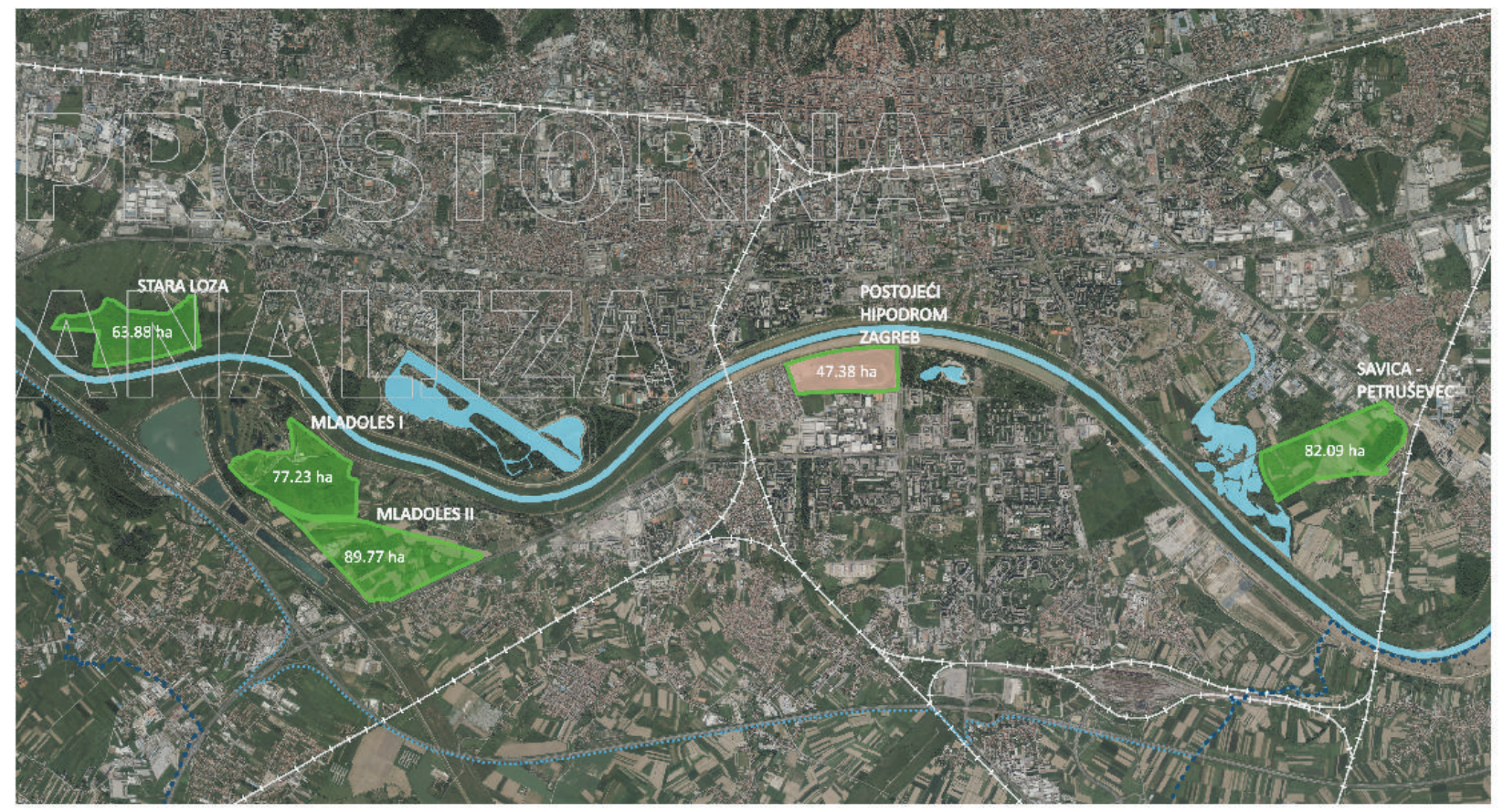

I2NOR:

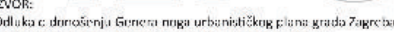

(5GG2 16/07, 8/C9, 7/13,9/16, 12/16 prozisscrni teksti)

Fig. 12 Spatial analysis of the Hippodrome. Source: GUSPRG.

Slika 12. Prostorna analiza Hipodrom, izvor: GUSPRG.

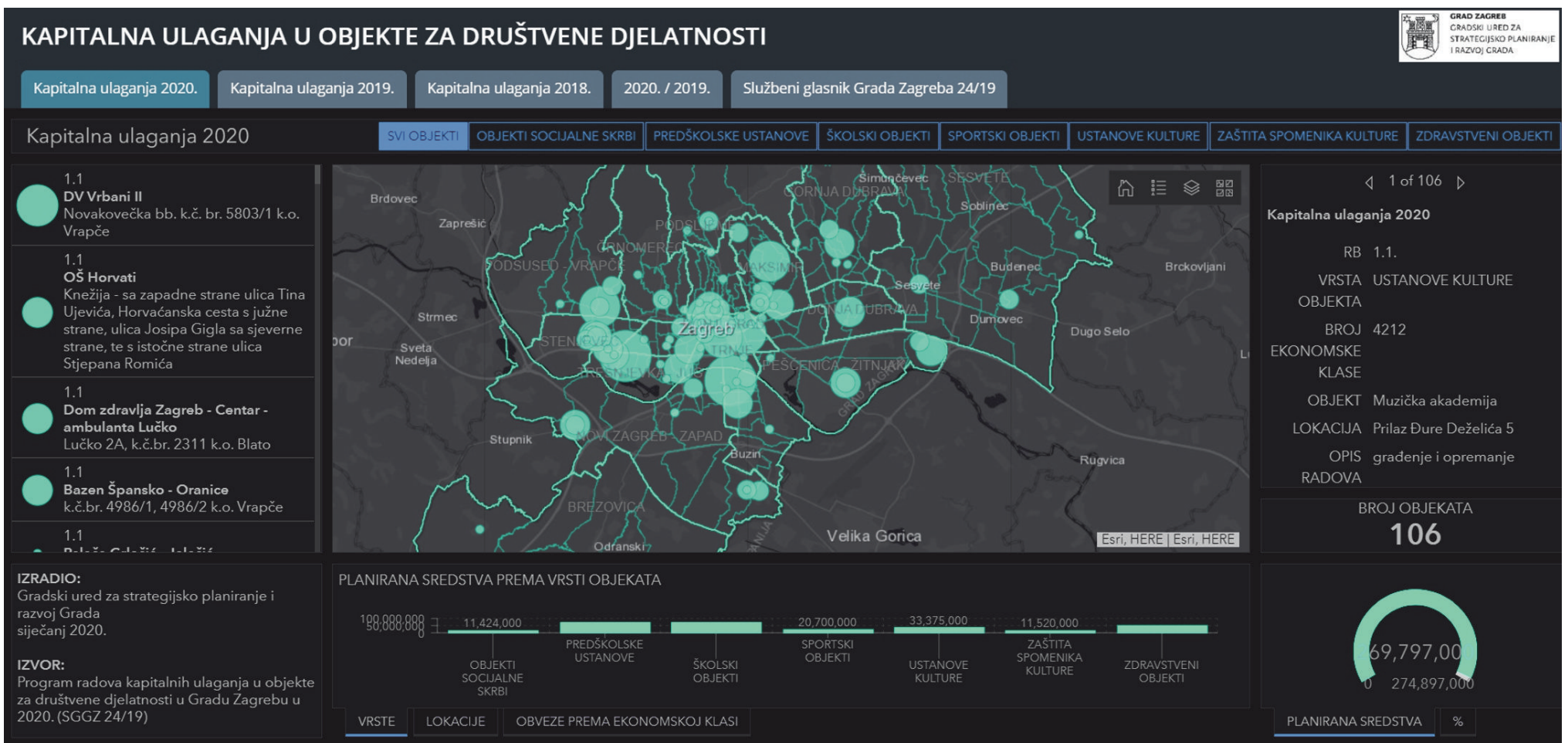

Fig. 13 Capital investments in facilities for social activities. Source: GUSPRG.

Slika 13. Kapitalna ulaganja u objekte za društvene djelatnosti, izvor: GUSPRG. 


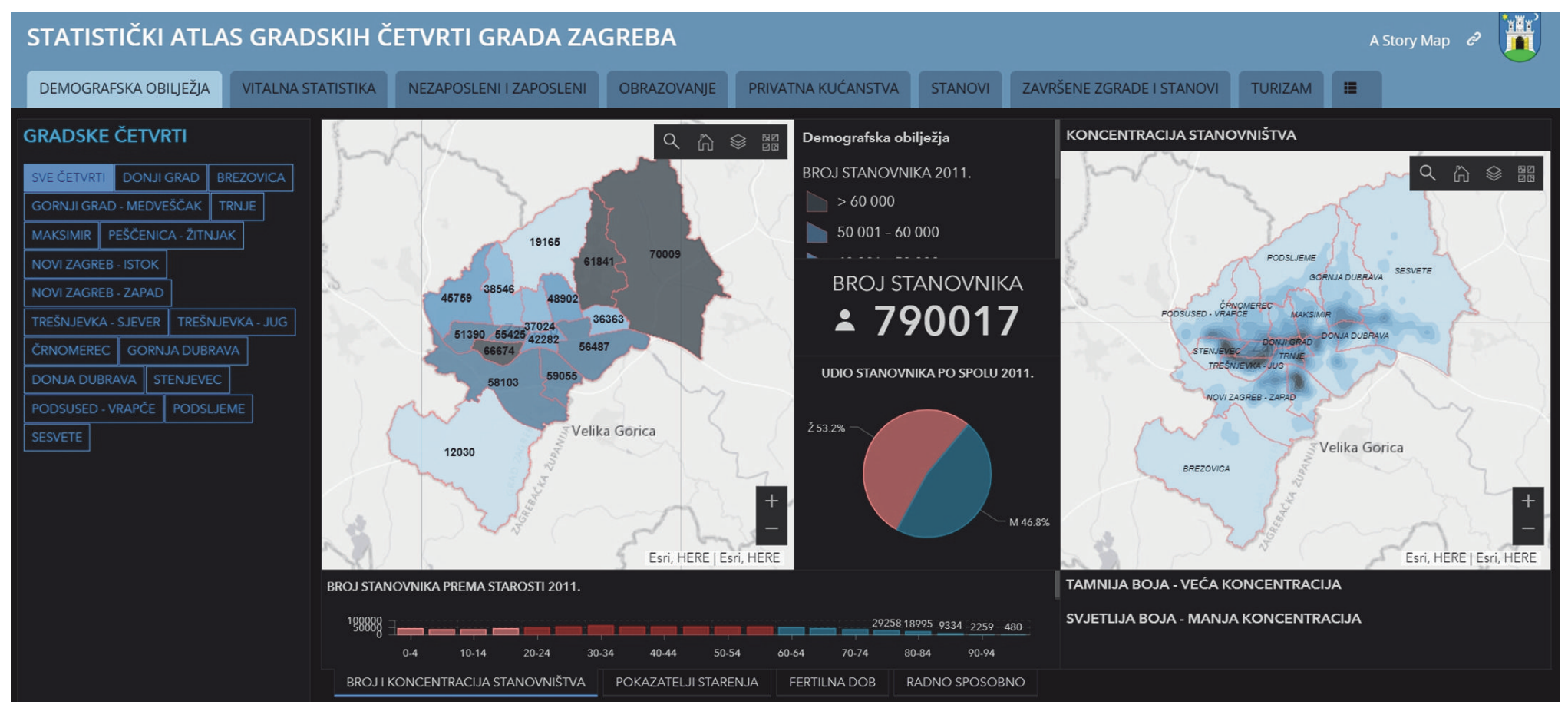

Fig. 15 Statistical Atlas of Districts in the City of Zagreb. Source: GUSPRG.

Slika 15. Statistički atlas gradskih četvrti Grada Zagreba, izvor: GUSPRG.

freshed data are immediately available, and the need to produce new analogue version is reduced.

Since the GUSPRG is also the bearer of the production of spatial plans, a web application has been prepared for the Sector for Spatial and Urban Planning, which shows the statistics for urban planning organisation in relation to the City of Zagreb Spatial Plan and General Urban Plan for Zagreb and Sesvete. It is possible to select plans according to dominant use, year of adoption, status of adoption, and city district (Plans 2020).

As a contribution to improving the quality of life, a web application called City Capital Investments in Facilities for Social Activities (Investments 2020) has been published, on which the budgeted investments resources for 2020 for building preschools, primary and secondary schools, health institutions, sports facilities, cultural institutions and social welfare facilities can be seen. These can be compared with the budgets for 2018 and 2019, since the information is published continuously (Figure 13).

The ever-present topic of architecture-urbanism tenders conducted in the City of Zagreb has been published as a web application with search options according to completion, year of implementation, purpose, type of tender, aim, status and city district (Tenders 2020). The application has been produced with the aim of achieving a greater degree of completion of implemented tenders, and to allow local self-government units access to the data from 2003 onwards (Figure 14).
For the purposes of the GUSPRG and local self-government, a web application called Statistical Atlas of Districts in the City of Zagreb (Atlas 2020) has been prepared. Every year, data are updated on demographic information, vital statistics, employed and unemployed persons, education, private households, apartments, completed buildings and tourist apartments by city district (Figure 15). Spatial and statistical analyses of city districts were produced in analogue format for the 2018 data, and this example shows the advantages of new technology in making data accessible to the public as they are updated.

On 22 March 2020, the City of Zagreb experienced a strong earthquake (5.5 on the Richter scale) with the epicentre in Markuševac. Considerable material damage was recorded in the historical city centre, and on 23 March 2020 the Mayor of Zagreb announced a natural disaster caused by the earthquake.

For the needs of the Office for Administration in Emergencies, which is the headquarters where several hundred volunteers and civil engineering experts (mostly structural engineers) are coordinated, who visit damaged buildings based on reports by citizens and other notifications, carry out preliminary in-

Fig. 16 Reports of damage following the earthquake in the City of Zagreb.

Slika 16. Prijave šteta nakon potresa na području Grada Zagreba.

KiG No. 33, Vol. 19, 2020, https://doi.org/10.32909/kg.19.33.3 


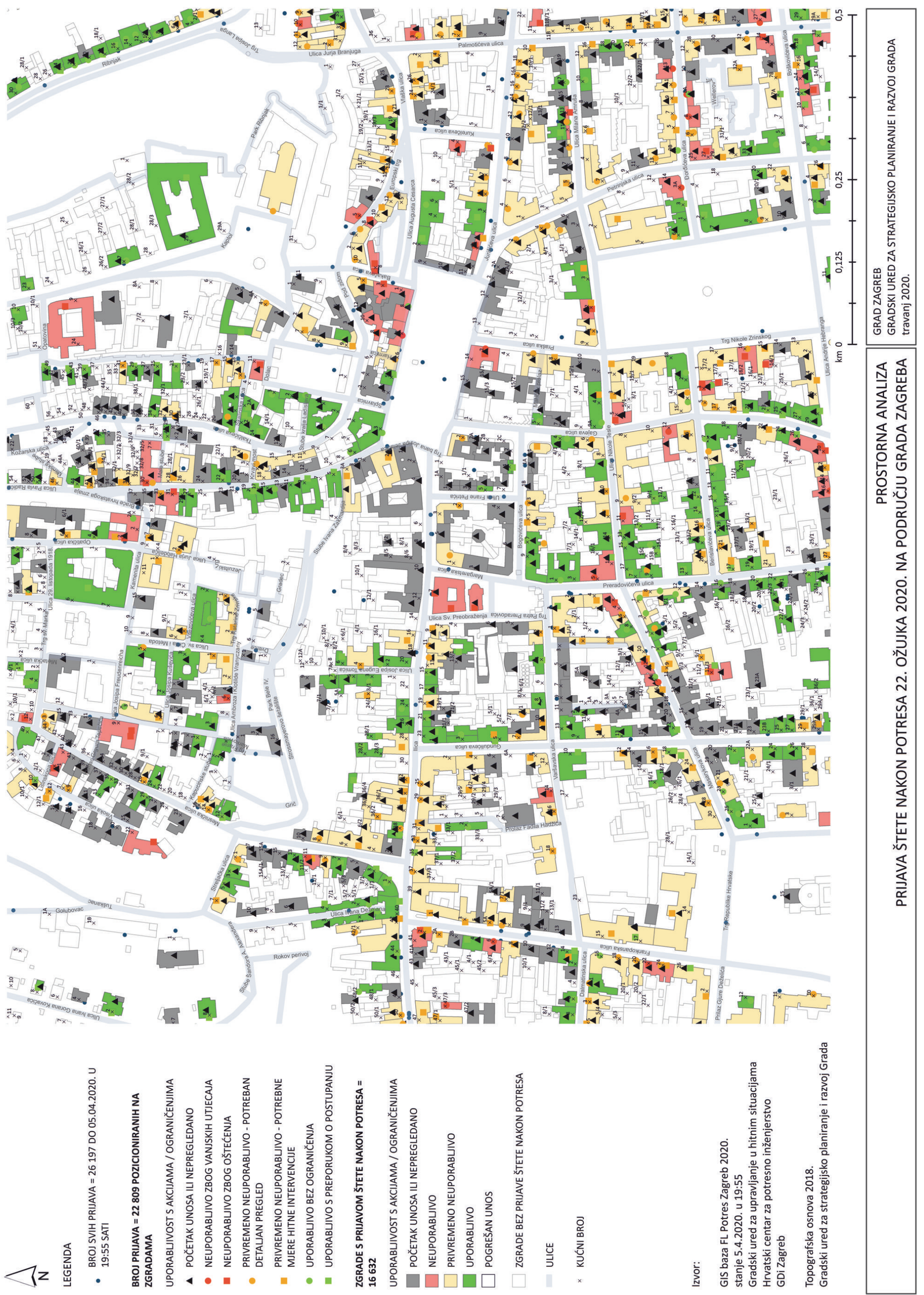


BROJ PRIJAVA u nedjelju 7.4.2020. u 19:55 sati = 26197

NUMBER OF REPORTS up to Sunday 7 April 2020 at $19.55=26,197$

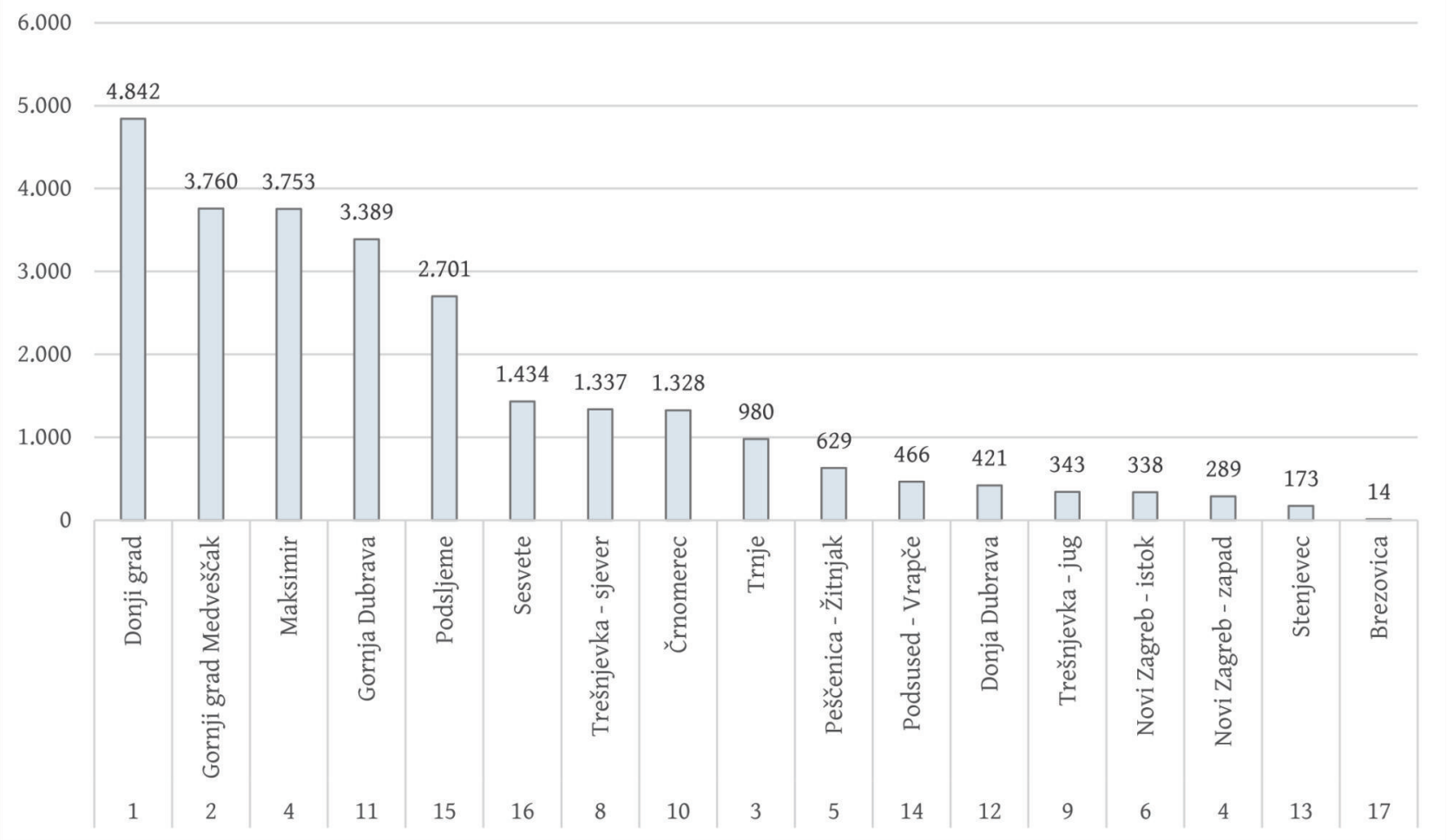

Fig. 17 Reports of damage following the earthquake by city districts.

Slika 17. Prijave šteta nakon potresa prema gradskim četvrtima.

spections and collect the relevant data according to a predetermined methodology, then issue recommendations to citizens regarding the fitness for use of buildings and the necessary interventions, the Estimate of the Number of Buildings Reported with Earthquake Damage has been produced. Reports were collected through an online application (Survey 123 for ArcGIS, prepared by GDi Zagreb), and by telephone and email. Over 26,000 reports were received. In the GIS base, which changes daily, there are examples of the same building being reported several times, some reports do not include the address of the building but only its location on a map, and others are incomplete or incorrectly located. By overlapping the points marked as "Reports of Damage" and "Buildings" from the 2018 Topographic Base, the first working estimate was produced (Figure 16), in which it was concluded that approximately 17,000 buildings were damaged in the earthquake (Figure 17). When the application for reporting damage is closed and recommendations on fitness for use regarding all the reported buildings are complete, a GIS base will be organised, as this will be an essential tool in renovation work in Zagreb following the earthquake.

\section{Conclusion}

Spatial analyses facilitate the management of spatial resources, help in priority decision-making, and are an essential basis in spatial and urban planning. The inventorisation of spatial data is under way, initial GIS bases are constantly being set up and, as needed, built up, updated and stored so that they are available to all users, whether city administration bodies or citizens, institutions, the scientific community or other interested parties. Since there are no prescribed standards for all types of data, examples from practice are often used to create new spatial data, and since there is a lack of regulations for producing urban analyses, examples from archival spatial plans, specific requests for particular tasks, or examples and norms from abroad are also used.

The GUSPRG, as the ZIPP coordinator, produces, maintains and publishes a large number of spatial data for the City of Zagreb. For the needs of the GUSPRG and other city administration bodies, we perform analyses which are publicly accessible to citizens on the City's website (Information 2020).

KiG No. 33, Vol. 19, 2020, https://doi.org/10.32909/kg.19.33.3 - 
Preklapanjem točaka 'Prijava štete' i 'zgrada' iz Topografske osnove 2018. pripremljena je prva radna procjena (slika 16) u kojoj je zaključeno da je šteta od potresa prijavljena na približno 17000 zgrada (slika 17). Po zatvaranju aplikacije s prijavama i nakon preporuka o uporabljivosti svih prijavljenih zgrada pristupit će se uređivanju GIS baze koja će biti nezaobilazna podloga u obnovi Zagreba nakon potresa.

\section{Zaključak}

Prostorne analize olakšavaju upravljanje prostornim resursima, pomažu u odlučivanju kod izrade prioriteta i obavezna su podloga za prostorno i urbanističko planiranje. Inventarizacija prostornih podataka je u tijeku, kontinuirano se postavljaju početne GIS baze koje se prema potrebi nadograđuju, ažuriraju i pohranjuju tako da su dostupne svim korisnicima, kako gradskoj upravi tako građanima, institucijama, znanstvenoj zajednici i svima zainteresiranima. S obzirom na to da nema propisane standardizacije za sve vrste podataka, često se koriste primjeri iz prakse kao poticaj za stvaranje novih prostornih podataka, isto tako zbog nepostojanja propisa za izradu urbanističkih analiza, koriste se primjeri iz arhivskih prostornih planova, specifični zahtjevi određenog zadatka ili strani primjeri i normativi.

GUSPRG kao koordinator ZIPP-a izrađuje, održava i objavljuje veliki broj prostornih podataka Grada Zagreba. Za potrebe GUSPRG-a i drugih gradskih upravnih tijela provodimo analize koje su javno dostupne građanima na web stranici Grada (Informacije 2020).

\section{References / Literatura}

AF (2019) Prostorno planska dokumentacija Zagreba i Zagrebačkog područja 20. stoljeća i početka 21. stoljeća, Čimbenici koji su utjecali na provedbu planova od 1986. godine, Arhitektonski fakultet, Zavod za urbanizam, prostorno planiranje i pejzažnu arhitekturu

Atlas (2020) Statistički atlas gradskih četvrti Grada Zagreba, https://zagreb.maps.arcgis.com/apps/MapSeries/index.html?appid=73e33727fad74298a9df9859a2331cd6, 14.4.2020.

Čengić, D. (1995) Razvoj uprave grada Zagreba u razdoblju 1919-1945. godine, Arh. vjesn., god. 38 (1995) str. 115-132

DZS (2020) Popis stanovništva 2011., Državni zavod za statistiku, https://www.dzs.hr/Hrv/censuses/census2011/censuslogo.htm, 10. 4. 2020.

Eurostat (2019) Eurostat, https://ec.europa.eu/eurostat/data/database, 19. 7. 2019.

Geoportal ZIPP-a (2020) ZG Geoportal, https://geoportal.zagreb.hr/Default.aspx, 10. 4. 2020.

GUSPRG (2020) Grad Zagreb, https://www.zagreb.hr/gradski-ured-za-strategijsko-planiranje-i-razvoj-g/821, 10. 4. 2020.

Informacije (2020) Prostorne informacije i istraživanja, https://www.zagreb.hr/prostorne-informacije-i-istrazivanja/47779, 14. 4. 2020.

Kahle, D. (2006) Građevinski propisi za grad Zagreb u razdoblju od 1919. do 1931. godine i Građevinski zakon iz 1931. godine, Znanstveni prilozi, Prostor, Vol. 14 No. 1(31), 2006., 116-129

Ljetopis (2020) Statistički ljetopis Grada Zagreba, https://www.zagreb.hr/statisticki-ljetopis-grada-zagreba/1044, 10. 4. 2020.

Narodne novine (2008a) Državni pedagoški standard predškolskog odgoja i naobrazbe, 63.

Narodne novine (2008b) Državni pedagoški standard osnovnoškolskog sustava odgoja i obrazovanja, 63.

Narodne novine (2012) Mreža javne zdravstvene službe, 101.

Narodne novine (2013) Zakon o nacionalnoj infrastrukturi prostornih podataka, br. 56

Narodne novine (2018) Zakon o nacionalnoj infrastrukturi prostornih podataka, br. 52, Članak 5, 13, 14, 25

Natječaji (2020) Javni arhitektonsko-urbanistički natječaji,

https://www.arcgis.com/apps/opsdashboard/index.html\#/ee188e9134864ec8a1d1c03842d47b73, 14.4.2020.

Planovi (2020) Urbanistički planovi uređenja,

https://www.arcgis.com/apps/opsdashboard/index.html\#/cf03d98d642b4b18b02b60f521c5594b, 14. 4. 2020.

Schwalbach, Gerrit (2009) Basics Urban Analysis, 38-70

Sektor (2020) Grad Zagreb, https://www.zagreb.hr/sektor-za-strategijske-informacije-i-istrazivanja/7244, 10. 4. 2020.

SGGZ (2018) Prostorni plan Grada Zagreba, pročišćeni tekst, Službeni glasnik Grada Zagreba

Strategija (2020) Strategija razvoja urbane aglomeracije Zagreb za razdoblje do 2020. godine, https://www.zagreb.hr/strategijarazvoja-urbane-aglomeracije-zagreb/86895, 22. 6. 2016.

Ulaganja (2020) Kapitalna ulaganja u objekte za društvene djelatnosti,

https://www.arcgis.com/apps/MapSeries/index.html?appid=bd0d17480d6a4067990497a5e6cbe52c, 14. 4. 2020. 